\title{
New Records of Philippine Mosses from Mindanao Island
}

\author{
LESLEY C. LUBOS \\ Dawsonia@yahoo.com \\ Liceo de Cagayan University
}

Date Submitted: January 14, 2007

Final Revision Accepted: July 16, 2007

Abstract-Thestudy identified the record status of the collected species of mosses found on selected mountains in Mindanao. Field collections of mosses were conducted in Mt. Kalatungan, Bukidnon Province and Mt. Matutum, South Cotabato Province at 10 meters on each side of the trails. The study sites were labeled Southeastern, Northeastern and Western Sloes. The moss specimens were collected, classified and described. Using the key of Bartram (1939) and other literatures, the specimens were identified. The study revealed 137 species, 87 genera and 33 families of mosses. Of the 137 species, 109 were found in Mt. Kalatungan and 59 in Mt. Matutum. Assessment of conservation status revealed seven new records of Philippines mosses namely: Acroporium ramicola, Garovaglia bauerlenii, Hypnodendron auricomum, Leucobryum boninense, Meiotheciella papillosa, Neolindbergia cladomnioides, and Symphysodontella parvifolia are reported. The annihilation of the mountains is basically caused by human activities such as land clearing, slash and burn method for expanding crop plantation, urbanization, firewood consumption, over collection of moss plant materials of horticulture, landscaping and other commercial purposes. Some species are epiphytes on tree trunks or branches of live trees while others are on rotten logs, rock surfaces, moist stones along the stream banks and some grow well on soil.

Key words - Mosses,Acroporium ramicola, Garovaglia bauerlenii, Hypnodendron auricomum, Leucobryum boninense, Meiotheciella papillosa, Neolindbergia cladomnioides, and Symphysodontella parvifolia. 


\section{INTRODUCTION}

The large and diverse Philippine (Fig 1) moss flora has a modern checklist (Tan and Iwatsuki 1991). The history and progress of Philippine bryology were reviewed and summarized by Tan (1992) who discussed in detail the floristic composition and affinity of the archipelagic moss flora (see also Tan 1984). In Tan's publications, Mindanao was cited as an important island, albeit with a still incompletely known flora, which may hold critically the key to a better understanding of the origin and evolution of the entire Philippine moss flora.

In recent years, the Island of Mindanao(Fig 2) has been alleged to have a different geological origin and plate tectonic history from the rest of the islands forming the Philippine archipelago (Hall 1998). As such, this second largest southern island of the country may harbor important floristic and bryogeographical information that needs to be documented before the local forests become completely decimated.

To date, Mindanao Island has a total of 187 genera and 314 species of mosses (cf. Tan and Iwatsuki 1991), 50 of which are known only from this island. The rest are found also in Luzon and the Visayas Islands. Among the 50 species of Philippine mosses known from Mindanao, 4\% are widespread in the tropics, $60 \%$ are Malaysian taxa, 21\% have an Australasian link, 10\% have a Bornean link, and only $6 \%$ have a continental Asiatic connection. Clearly, the moss flora of Mindanao has a strong southern and Australasian influence compared to other large islands in the country (see also Tan 1998).

\section{OBJECTIVE OF THE STUDY}

The objective of the study is to identify the record status of the collected species of mosses found in selected mountains in Mindanao.

\section{MATERIALS AND METHODS}

\section{Survey Establishment of the Study Sites}

Survey of mosses in Mt. Kalatungan, Bukidnon Province (Fig 3); and Mt. Matutum (Fig 4), Tupi, South Cotabato Province, was conducted at the three slopes or areas of the forest reserve: western slope, northern slope, and southeastern slope. Furthermore, a compass was used to determine the exact direction of the slopes or areas. These areas were selected because of their accessibility. 


\section{Collection of Specimens}

Representative species of mosses whether terrestrial, epiphytic or petrophytic, were collected at $10 \mathrm{~m}$ of each side of the trail from base to the upper portion of the three selected areas. The collection was done using a knife and a bolo and was placed in a plastic bag, labeled with following data: altitude, collection number, date of collection, and their associated habitat.

\section{Classification, Identification and Description}

The specimens collected were classified and identified using the taxonomic keys of Bartram (1939). Each species identified was described morphologically using the gametophyte characters (leaf arrangement, midrib, base, apex, margin, cells, and shape) and sporophyte characters (size, shape, texture of capsule and seta, number of teeth).

\section{Data Sources}

In addition to the researcher's collections, data from the electronic database of Dr. Benito C. Tan of the National Herbarium in Singapore, where the researcher's duplicate specimens were deposited for identification and analysis, were used.

\section{Photographs}

A camera was used for documentation. Stereomicroscope and trinocular microscope were also used to describe the morphology of the species.

\section{Record Status}

A New Annotated Checklist of Iwatsuki and Tan (1991) were used to determine the record status of the species.

\section{RESULTS AND DISCUSSION}

The study found out that there are new records of mosses found in Mindanao Mountains (Fig 5), six in Mt. Kalatungan and one in Mt Matutum.

\section{Acroporium ramicola (Hampe) Broth. [Family Sematophyllaceae ]}

According to Tan (1994), this is a difficult species to interpret and identify. Having erect, spreading and acicular leaves when dry, it is like a large version of the common A. diminutum (Brid.) Fleisch. The leaf cells of Acroporium ramicola are clearly unipapillose, whereas the leaf cells of A. diminutum are generally smooth and occasionally prorate. Acroporium ramicola also looks like A. convolutum (Bosch \& Sande Lac.) Fleisch. The latter, however, has ovatelanceolate leaves, quite unlike the narrowly lanceolate and tightly involutes leaves of A. ramicola.

The present species was first described in Sarawak of Borneo and later reported in Papua New Guinea (Tan 1994). The new Philippine (Mindanao) record would seem to indicate that the species is probably widely scattered across the region but 
overlooked by plant collectors.

Specimens Studied: Mt. Kalatungan, Bukidnon Province

\section{Garovaglia bauerlenii ( Geh.) Par. [Family Pterobyaceae]}

This is a large and beautiful species of Garovaglia characterized by a tumid foliation with strongly rugose as well as plicate leaves. The leaves are broadly ovate. The leaf apices are abruptly acute to gradually acuminate and the leaf base has neither auricular nor decurrent development. The species seems uncommon in the Malaysian region having been collected sporadically from Peninsular Malaya and Papua New Guinea, and now, Mindanao. It is a new moss record for the Philippine archipelago.

Specimens Studied: Mt. Kalatungan, Bukidnon Province

\section{Hypnodendron auricomum Broth. \& Geh. [Family Hypnodendraceae]}

Hypnodendron auricomun is a relatively common Malaysian species found in many high mountains south of the Philippines. Hence, it is most welcome to see this among our Mindanao collections.

Among its congeners, the species is distinctive in having an umbellate branching habit with a long stripe and numerous appressed stripe leaves (Norris and Koponen 1996). In New Guinea, the species is reportedly rather variable in plant size, being larger at higher elevations (Touw 1971).

The addition of this species to the Mindanao flora highlights the past Gondwanic connection of the island flora.

Specimens Studied: Mt. Kalatungan, Bukidnon Province

\section{Leucobryum boninense Sull. E Lesq. [Family Leucobryaceae]}

This species is new to the Philippines. The size of Mindanao plants approaches that of L. javense (Schwaegr.) Mitt., but the plant habit looks more like a L. bowringii Mitt. The species identity was confirmed by Dr. T. Yamaguchi (1999, pers. comm.) who wrote that "although the (Mindanao) plants are larger that those of typical L. boninense; the leaf shape and the proration of abaxial leaf cells are similar to the typical form." Although the species was reported in Yamaguchi (1993) as ranging from Japan, China to Taiwan, it is probably well distributed in Malaysia. Leucobryum boninense appears to be new not just to the Philippines, but also to Malaysia.

Specimens Studied: Mt. Kalatungan, Bukidnon Province 
5. Meiotheciella papillosa (Broth.) B. C. Tan, Schof. E Ramsay [Family Sematophyllaceae]

Meiotheciella is a segregate genus of Meiothecium characterized by having unipapillose leaf cells, among other characters. The genus and the species are both new records for the Philippine flora. The plants are small, half the size of the widespread Meiothecium microcarpum (Hook.) Mitt, or about the size of M. bogoriense Fleisch. The leaves of the Mindanao plants are ovate and narrowly recurved on both sides. The leaf cells are mostly short oval becoming oblong at leaf base. Tan, Schofield and Ramsay (1998) provided a good illustration of the taxon.

Meiotheciella papillosa is now known in the Philippines (Mindanao), Java, New Caledonia, and Australia (Queensland). It should be sought for from the intervening islands in the Malaysian region.

Specimens Studied: Mt. Kalatungan, Bukidnon Province

6. Neolindbergia cladomnioides Akiyama [Family Prionodontaceae]

The species is new to the Philippine flora. It was first described in Mt. Kinabalu in Sabah of Malaysia by Akiyama et al. (1991) and subsequently found also in East Kalimantan. Its presence in Mindanao is an indication of the close phytogeographical relationship between Mindanao and Sabah State of Borneo. The species is unique, having rather large, stout and ascending shoots with strongly plicate and serrate leaves. The erect shoots measure to $8-10 \mathrm{~cm}$ long and $2-3 \mathrm{~mm}$ wide. This species is best illustrated by Akiyama et.al (1991).

Specimens Studied: Mt. Matutum, South Cotabato

7. Symphysodontella parvifolia Bartr. [Family Pterobryaceae]

This species is unique in the genus, having distinctly long apiculate leaf apices. The ascending shoots of the Philippine (Mindanao) plants are fiabellate in branching pattern. Several flagellate tertiary branches are conspicuously formed distally. The species is known in the Lesser Sunda Islands, Moluccas Islands, and New Guinea (Magill 1980; Touw 1992). It is reported for the first time in the Philippines.

Specimens Studied: Mt. Kalatungan, Bukidnon Province

\section{CONCLUSION}

The study found out that there are new records of mosses found in Mindanao, particularly in Mt.Kalatungan in Bukidnon, and Mt. Matutum in South Cotabato. These Philippine mountains need to be protected and preserved in order to ensure mosses' growth and abundance. Protection of the mosses is protection of our forest ecosystem. 


\section{LITERATURE CITED}

Akiyama, H., T. Koponen and D. H. Norris. (1991).Bryophyte flora of the Huon Peninsula, Papua New Guinea. XLV, Neolindbergia (Prionodontaceae, Musci). Acta Bot.Fennica 143: 77-89.

Hall, R. (1998). The plate tectonics of Cenozoic SEAsia and the distribution of land and sea,pp. 99-131. In: R. Hall \& J. D. Holloway(eds.), Biogeography and Geological Evolution of SE Asia. Backhuys Publisher,Leiden.

Magill, R. (1980). A monograph of the genus Symphysodontella (Pterobryaceae, Musci). J. Hattori Bot. Lab. 48: 33-70.

Noguchi, A. (1976). A taxonomic revision of the family Meteoriaceae of Asia. J. Hattori Bot. Lab. 41: 231-357.

Norris, D. H. and T. Koponen. (1996). Bryophyte flora of the Huon Peninsula, Papua New Guinea. LVIII. Hypnodendron (Hypnodendraceae, Musci). Acta Bot. Fennica 156: 23-48.

Tan, B. C. (1984). A reconsideration of the affinity of Philippine moss flora. 3. Hattori Bot. Lab. 55: 13-22.

Tan, B. C. (1992). Philippine muscology (1979-1989).In: T. Koponen and J. Hyvönen (eds.).Proceedings of the Congress of East Asiatic Bryology, Helsinki, August 12-19, 1990. Bryobrothera 1: 137-141.

Tan, B. C. (1994). The bryophytes of Sabah (North Borneo) with special reference to the BRYOTROP transect of Mount Kinabalu. XIX. The genus Acroporium (Sematophyllaceae, Musci) in Borneo, with notes on species of Java and the Philippines. Willdnowia 24: 255-294.

Tan, B. C. (1998). Noteworthy disjunctive patterns of Malesian mosses, pp. 235241. In: R. Hall \& J. D. Holloway (eds.), Biogeography and Geological Evolution of SE Asia. Backhuys Publisher, Leiden.

Tan, B. C. and Z. Iwatsuki. (1991). A new annotated Philippine moss checklist. Harvard Papers Bot. 3: 1

Tan, B. C., W. B. Schofield and H. Ramsay. (1998). Miscellanies of Australian Sematophyllaceae with a new genus, Meiotheciella. Nova Hedwigia 67: 2 13-223.

Touw, A. (1971). A taxonomic revision of the Hypnodendraceae (Musci). Blumea 19:211-354.

Touw, A. (1992). A survey of the mosses of the Lesser Sunda Islands (Nusa Tenggara), Indonesia. 3. Hattori Bot. Lab. 71: 289-366.

Yamaguchi, T. (1993). A revision of the genus Leucobryuin (Musci) in Asia. 3. Hattori Bot. Lab. 73: 1-123. 


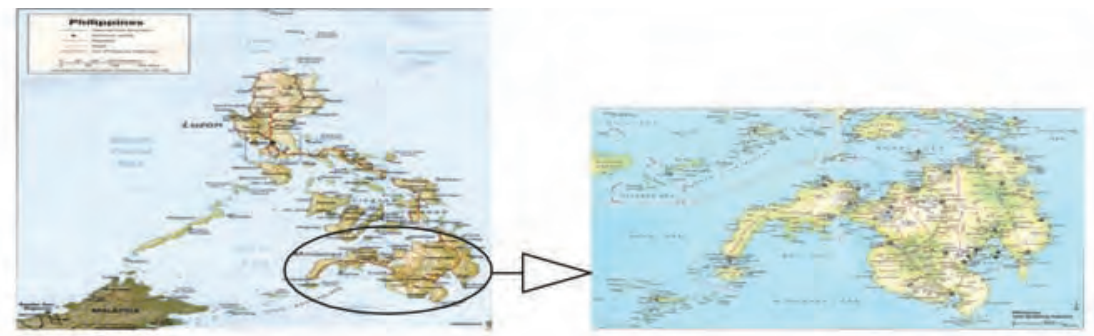

Fig. 1 Philippine Map

Fig. 2 Mindanao Island

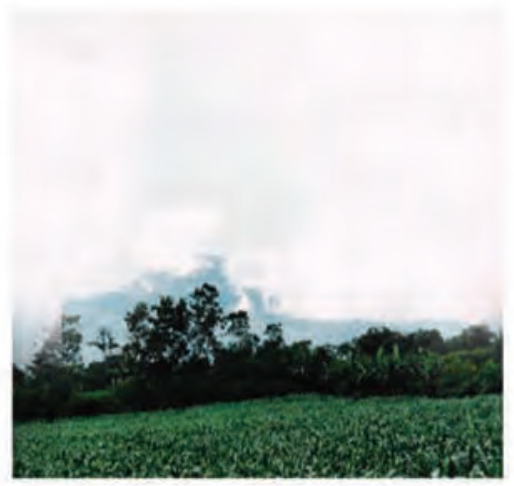

Fig. 3 Mt. Kalatungan, Bukidnon Province

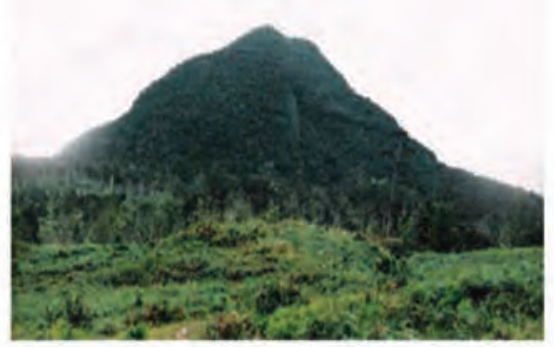

Fig. 4 Mt. Matutum, South Cotabato

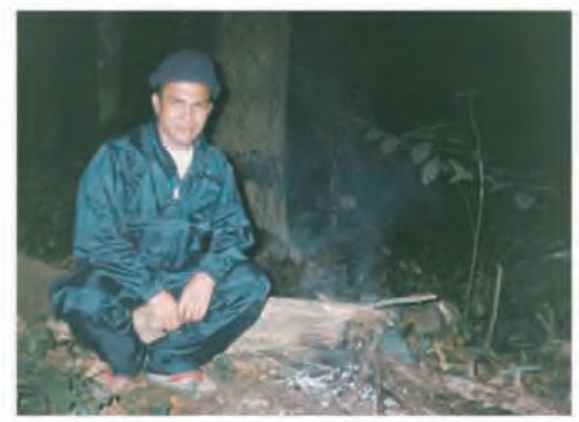

The Researcher 


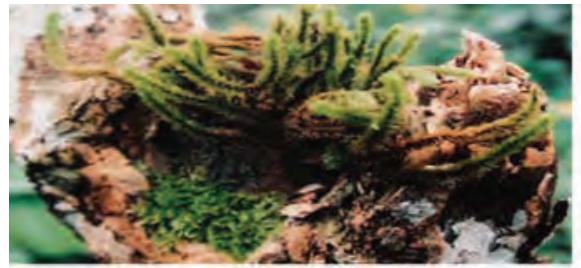

a. Neolindbergia cladomnioides Akiyama

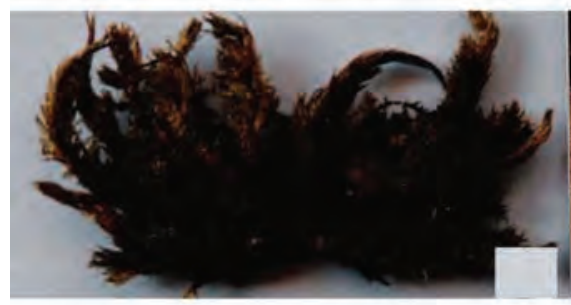

c. Symphysodontella parvifolia Bartr.

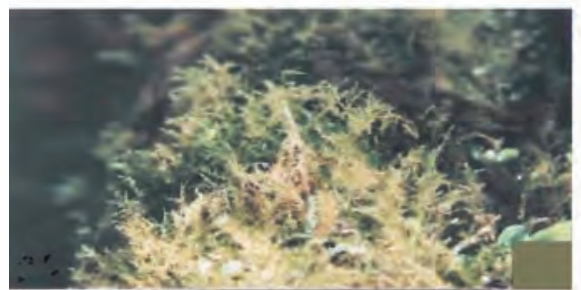

e. Meiotheciella papillosa (Broth.) B.C.Tan,Schof.\& Ramsay

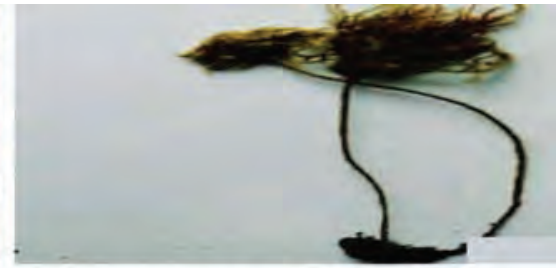

b. Hypnodendron auricomum Broth. \& Geh.

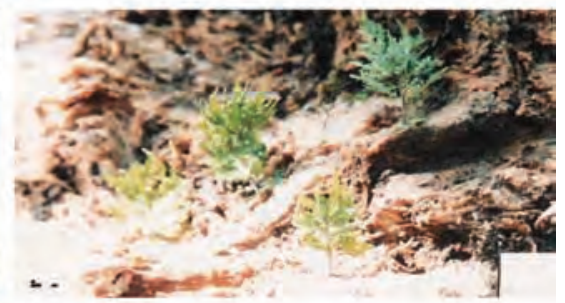

d. Acroporium ramicola (Hampe) Broth

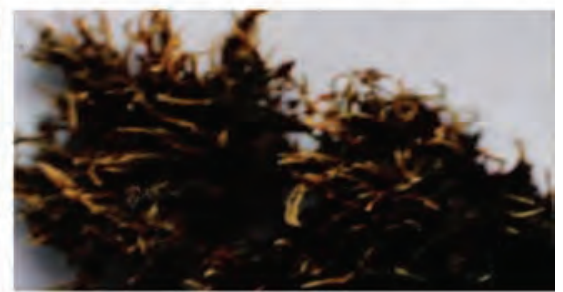

f. Leucobryum boninense Sull. \& Lesq.

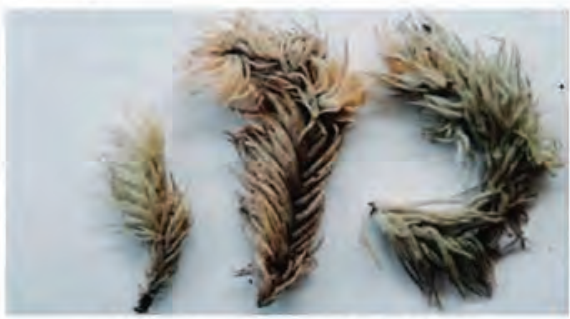

g. Leucobryum boninense Sull. \& Lesq.

Fig. 5 Seven New Records of Philippine Mosses 